\title{
$\begin{array}{lllllllll}\mathrm{I} & \mathrm{N} & \mathrm{S} & \mathrm{T} & \mathrm{I} & \mathrm{T} & \mathrm{U} & \mathrm{T} & \mathrm{E}\end{array}$
}

\section{Education in Chronically Poor Rural Areas Lags Across Generations}

$\mathrm{E}$ ducation levels vary substantially across America's rural regions. Most rural communities fall into one of four general types: amenity-rich, amenity-transition, declining resource-dependent, and chronically poor (see the Definitions box). ${ }^{1}$ This typology is useful for investigating broad trends between rural community types, including the education level of residents and their parents. Rather than conceptualizing rural America as a homogenous place with similar strengths and weaknesses, this typology allows for comparisons between some very different parts of rural America.

Figure 1 shows the education levels typical of each type of rural community, based on survey research for the Community and Environment in Rural America (CERA) initiative. Since 2007, Carsey Institute researchers have conducted over 17,000 telephone surveys with randomly selected adult Americans (age 18 and above) from twelve diverse rural locations. ${ }^{2}$ Each CERA survey location is categorized at the county level as one of the four rural types. CERA survey respondents are asked a variety questions about their opinions on general and place-specific socioeconomic and environmental issues potentially affecting their lives, families, or communities, and data are gathered about respondents' demographic characteristics. Respondents were asked about both their own and their parents' educational attainment. They were also asked about their perceptions of school quality in their communities.

Unsurprisingly, CERA surveys found significantly lower education levels in chronically poor communities, compared with amenity-rich, amenity-transition, and declining communities (see Figure 1). Although 14 percent of those in chronically poor communities report not completing high school, only 6 percent in amenity-transition, 4 percent in declining, and 2 percent in amenity-rich communities report the same. A higher percentage of respondents from chronically poor regions said high school was their highest level of education, and fewer report completing or attending college

\section{Key Findings}

Since 2007, Carsey researchers have surveyed 17,305 rural Americans about a wide variety of social, economic, and environmental issues. Key findings from the Community and Environment in Rural America (CERA) survey regarding education include the following:

- Educational achievement varies significantly by type of place in rural America. In chronically poor rural areas, 45 percent of residents have completed only high school or less, compared with 22 to 33 percent in amenity-rich, amenitytransition, and declining resource-dependent rural areas. ${ }^{3}$

- Parents of respondents in amenity-rich and amenity-transition rural communities have higher levels of education than parents of respondents in declining and chronically poor communities.

- Although people from all types of rural communities generally have more education than their parents, those in chronically poor rural areas still have relatively low education levelsa disadvantage that persists across generations. Fourteen percent of CERA respondents still report not completing high school.

- Concern about school quality is highest in chronically poor rural places where education levels are lowest; however, respondents from declining resource-dependent places were less concerned about school quality than respondents from amenity-rich and amenitytransition rural communities. 


\section{Definitions: Four Types of Rural Communities}

Amenity-rich rural places are characterized by high levels of population growth; abundant natural amenities that are attractive to tourists, retirees, and outdoor enthusiasts; and relatively high education levels, income, and employment. Some residents in these rural places worry about the effects of dramatic population growth and sprawl on the natural environment, and the changing character of their communities. Park and Chaffee counties in Rocky Mountain states such as Colorado are examples of amenity-rich rural places.

Declining resource-dependent rural communities were once known for their strong resource-extractive industries such as forestry or agriculture that supported a strong blue-collar middle class. The decline in these industries has led to stagnant economic conditions and population decline, particularly among younger generations. However, because of past investment, education and employment rates remain relatively high and poverty rates relatively low. Many rural communities throughout the Midwest and Great Plains, such as Jewell, Osborne, Republic, and Smith counties in Kansas, are considered declining resource-dependent.

Chronically poor areas suffer from persistent poverty, high unemployment, and long-term underinvestment in their educational systems, infrastructure, and civic institutions. These areas are attracting few newcomers and are losing many young adults who are essential to healthy civic and economic life. Communities in the heart of Appalachia, such as Harlan and Letcher counties in Kentucky, the Mississippi Delta including Coahoma, Tunica, and Quitman counties, and the "Black Belt" of Alabama including Choctaw, Clarke, Marengo, and Wilcox counties, typify chronically poor rural areas.

Transitioning amenity-decline (amenity-transition) rural communities have traits similar to both amenity-rich and declining resource-dependent places. These places are experiencing declines in their more traditional industries but have been able to attract newcomers. Modest to low population growth and relatively high employment and education levels typify these communities. The Northwest and Northeast contain many rural communities that are considered transitioning amenitydecline. Amenity-transition places surveyed include counties in the Pacific Northwest, New England's North County, the Upper Peninsula of Michigan, Downeast Maine, and the Southeast Alaska panhandle.

than other rural residents. Seventy-eight percent of respondents from amenity-rich communities said they completed some college, technical, or graduate school while only about one-half ( 55 percent) of those from chronically poor regions said the same. Education levels of respondents in declining and amenity-transition communities fall between amenityrich and chronically poor, but they more closely resemble those of amenity-rich respondents.
Figure 1. Respondent's Highest LeVel of Education Completed by Type of Place

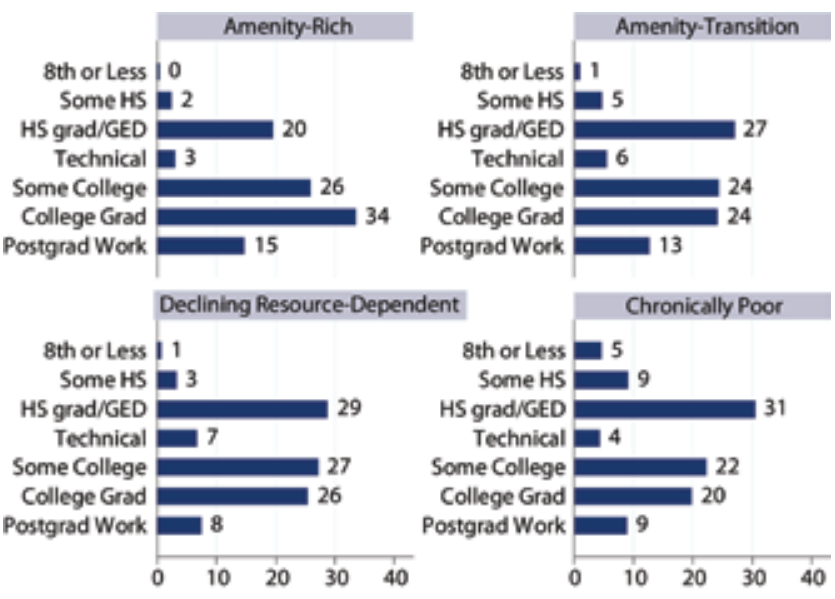

\section{Parents' Education by Rural Community Type}

The education level of respondents' parents also varies substantially by community type (see Figure 2). Educational patterns are similar for both parents, but, overall, fathers have slightly lower education levels than respondents' mothers. Parents' education is important because the educational attainment of children is often closely related to that of their parents. ${ }^{4}$ When parents place a high value on education, their children are more likely to have the encouragement and financial support to pursue education themselves. ${ }^{5}$

Parents of respondents from amenity-rich and amenitytransition rural communities had higher levels of education than those from declining and chronically poor communities. For example, nearly one-half (43 percent) of fathers from chronically poor rural areas had less than a high school education compared with only 19 percent of fathers from amenityrich areas. Almost one-third (30 percent) of the fathers from chronically poor places completed only the eighth grade or less. Similarly, 21 percent of the mothers from chronically poor places completed only eighth grade or less. The extremely low education level of respondents' parents in chronically poor rural areas underscores the lack of educational opportunities that have persisted for generations. ${ }^{6}$ Growing up in households with parents with low education levels and in communities with inadequate educational opportunities makes it difficult for those growing up in chronically poor rural areas to achieve a high level of education themselves. 
Although rural Americans from all community types have been able to attain higher education levels than their parents, their progress has not been uniform. The education levels attained by respondents from declining areas were the furthest from that of their parents. Those from amenity-rich and amenity-transition communities also made significant gains, but to a lesser degree than those from declining rural places. Fewer respondents from chronically poor regions, however, experienced the same degree of intergenerational upward mobility in their education levels. In other words, despite some progress, respondents in chronically poor rural areas still lag behind others in their educational attainment.

\section{Figure 2. Parents' Highest Level of Education} Completed by Type of Place

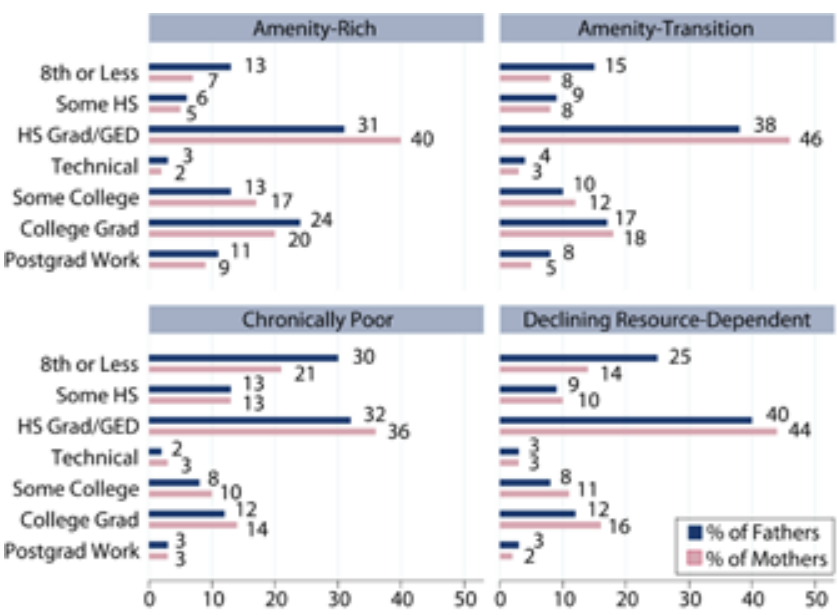

\section{Perceptions of School Quality}

CERA survey respondents were also asked if they thought that school quality was an important problem facing their community today. Subjective views of school quality are important to discuss along with more objective measures such as education levels because they provide a direct measure of how residents feel about the quality of schools in their community. Understanding perceptions of social issues can be as important as objective indicators in understanding how people respond to important community-level issues like education. If respondents don't perceive school quality to be a problem, they may not push local leaders for improvement in their school system. At the same time, those who are concerned about school quality may not have the financial or social resources to push for change.

Respondents from chronically poor places have the lowest education levels, and they are the most likely to perceive school quality in their community as a problem (see Figure 3).
Fifty-nine percent perceive school quality as problematic in comparison to only 27 percent of respondents from declining places. The relatively high levels of concern about school quality in chronically poor places reflect long-term underinvestment in the education systems. Those from amenity-rich and amenity-transition were in between with 43 and 52 percent concerned, respectively. Respondents from declining places had lower levels of education than those from amenity-rich and amenity-transition places, but they were less concerned with school quality in their community. Relatively positive opinions about school quality in declining resource-dependence places may reflect past investment in the school systems. Respondents from amenity-rich places might be more concerned about school quality than those from declining places because of the influx of new residents who are putting additional stress on the local school systems.

Figure 3. Percentage of Respondents Who Think School Quality Is an Important Problem Facing Their Community

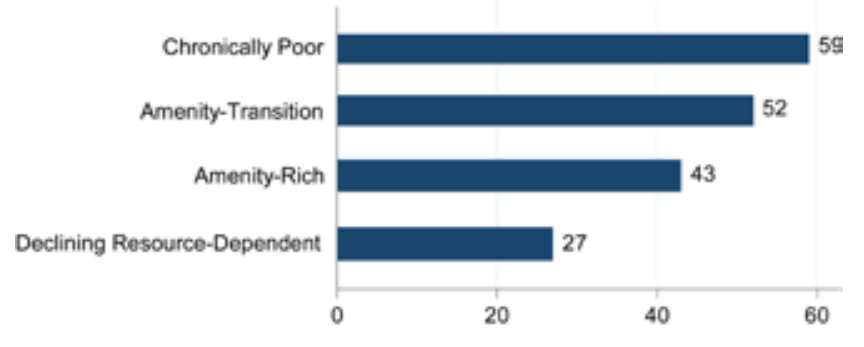

\section{Implications of Educational Trends}

There was a time, even a generation ago, when a strong back and good work ethic could mean a decent job and good life in rural America. ${ }^{7}$ Unfortunately, this is no longer the case. In today's increasingly competitive and unstable economy, rural Americans need increasingly higher levels of education or specialized technical skills to obtain even low-paying jobs. Thus, although education has for generations been a key predictor of economic success, ${ }^{8}$ it is even more important today simply for basic survival.

When those in poor communities lag so dramatically behind others in educational achievement, their future opportunities are dim. Although respondents from chronically poor places in the CERA survey were able to achieve higher levels of education than their parents, they still lag far behind rural residents in other places. In a context of low educational attainment and poor quality schools, it is not surprising that so few attain a high school diploma. Additionally, those from chronically poor areas are more likely than other rural residents to question the quality 
of education their schools currently provide. Despite this concern, they may not have the financial or social resources to push for improvement in their local school systems. These findings highlight the importance in investing in the educational systems of chronically poor rural areas where generations of underinvestment have contributed to persistent poverty.

\section{E N D N O T E S}

1. Lawrence C. Hamilton et al., "Place Matters: Challenges and Opportunities in Four Rural America," Reports on Rural America, vol. 1, no. 4 (Durham, NH: Carsey Institute, 2008).

2. These areas include rural counties in the states of Kansas, Colorado, Washington, Oregon, New Hampshire, Maine,

Mississippi, Kentucky, Alabama, Michigan, Vermont, Florida, and Alaska. The total number of respondents used in this analysis was 17,305.

3. All percentages using CERA data throughout this brief are calculated using weights based on recent census age, race, and sex estimates.

4. Stephen J. Caldas and Carl L. Bankston, Forced to Fail: The Paradox of School Desegregation (Lanham, MD: Rowman and Littlefield Education, 2005).

5. Annette Lareau, "Invisible Inequality: Social Class and Childrearing in Black Families and White Families," American Sociological Review, 67(5) (2002): 747-776.

6. Cynthia M. Duncan (editor), Rural Poverty in America (Westport, CT: Auburn House, 1992).

7. Peter Dreier, John Mollenkopf, and Todd Swanstrom, Place Matters: Metropolitics for the Twenty-First Century (Lawrence, KS: University Press of Kansas, 2004).

8. Peter Blau and Otis D. Duncan, The American Occupational Structure (New York: John Wiley \& Sons, 1976).

\section{A C K N O W L E D G M E N T S}

The author would like to thank Mil Duncan for her helpful insights on this brief, and for her support and encouragement while working on the CERA project, as well as Curt Grimm, Chris Colocousis, Beth Mattingly, Lawrence Hamilton, Laurel Lloyd Earnshaw, Barbara Ray, Amy Sterndale, Michelle Stranksky, and Suzanne Graham for their input on subsequent drafts.

\section{A B OUT THE AUTHOR}

Jessica D. Ulrich is a doctoral student in the Department of Sociology at the University of New Hampshire and a research assistant at the Carsey Institute (jessicad.ulrich@ gmail.com).

\section{ANIVERSITY}

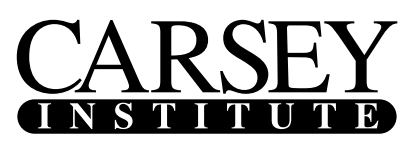

Building knowledge for families and communities

The Carsey Institute conducts policy research on vulnerable children, youth, and families and on sustainable community development. We give policy makers and practitioners timely, independent resources to effect change in their communities.

This work was supported by the Ford Foundation, the W. K. Kellogg Foundation, and the Neil and Louise Tillotson Foundation at the New Hampshire Charitable Foundation.

Huddleston Hall

73 Main Street

Durham, NH 03824

(603) 862-2821

www.carseyinstitute.unh.edu 